\title{
“CLUES" FOR DETERMINING WHETHER BUSINESS AND SERVICE INNOVATIONS ARE UNPATENTABLE ABSTRACT IDEAS
}

\author{
by \\ Pamela Samuelson $\mathcal{F}^{2}$ Jason Schultz ${ }^{*}$
}

The Supreme Court's decision in Bilski v. Kappos made it clear that generalized methods of financial hedging are abstract ideas that are ineligible for patent protection. However, the Court left the framework for determining abstraction versus concreteness in future cases unclear, offering only "clues" for drawing such distinctions.

In this Article, we attempt to provide the beginnings of such a framework. We start by discussing the clues we think are most likely to be useful to the U.S. Patent and Trademark Office and the courts in developing a jurisprudence of abstractness as a disqualification from patent protection. We then discuss why, in light of these clues and in line with sound patent policy, business and service method innovations, while not categorically unpatentable, should still generally be excluded from patent protection as abstract ideas. Finally, we provide further support for this approach by suggesting that taking the clues of unpatentability seriously may facilitate administrative and judicial efficiency in reviewing patent claims when assessing whether they satisfy patent subject matter mules.

I. INTRODUCTION

II. BILSKI DIRECTS US TO SEARCH FOR "CLUES" ABOUT

ABSTRACTNESS .................................................................... 112

A. Clues Derived from Bilski and Other Supreme Court Precedents... 112

B. The Constitution's Emphasis on Promoting Progress Provides Another Clue to Determining Abstractness..................................... 115

C. The Patent Act's Emphasis on Machines, Manufactures, and Compositions of Matter also Provides Clues to Distinguishing Abstract Ideas from Concrete Processes.

* Pamela Samuelson is the Richard M. Sherman Distinguished Professor of Law, Berkeley Law School. Jason Schultz is an Assistant Clinical Professor of Law, Berkeley Law School. This Article is a derivative work of a brief amicus curiae that the authors submitted on behalf of the Ewing Marion Kaufmann Foundation, the Electronic Frontier Foundation, and several entrepreneurs in support of the U.S. Patent \& Trademark Office (PTO) rejection of Bernard Bilski's patent application for failure to claim patentable subject matter. See Brief of Entrepreneurial \& Consumer Advocates as Amici Curiae Supporting Respondent, Bilski v. Kappos, 130 S. Ct. 3218 (2010) (No. 08-964). We wish to thank Eric Talley for his help with the arguments concerning innovation, competition, and financial arbitrage. 
III. THE ABSTRACTNESS “CLUES" AND SOUND PATENT POLICY SUGGEST THAT BUSINESS AND SERVICE PROCESSES ARE STILL OFTEN UNPATENTABLE 120

A. Patent Protection Is Generally Unnecessary to Promote Innovation in Business and Service Processes.

B. By Their Nature, Business and Service Innovators Have Not Needed Patent Incentives Because They Have Had Less Intensive $R \mathcal{E} D$ Costs than Technological Innovators.

C. Business and Service Innovations Are Often More Diffuse and Collaborative and Thus Fall Outside of the Classic Patent "Reward" Paradigm

D. Extensive Patent Protection on Business and Services Would Disrupt Settled Expectations and Impose Substantial Additional Costs on Innovators and Investors.

IV. USING ABSTRACTNESS CLUES TO CLOSELY SCRUTINIZE PATENT APPLICATIONS ON BUSINESS AND SERVICE PROCESSES WILL IMPROVE ADMINISTRATIVE AND JUDICIAL EFFICIENCY.

A. Use of Robust \$ 101 Clues Allows the PTO to Efficiently Reject Abstract Patent Applications

B. Use of Robust $\$ 101$ Clues Allows Courts to Efficiently Dismiss Frivolous Patent Litigation

IV. CONCLUSION

\section{INTRODUCTION}

In June 2010, the U.S. Supreme Court ruled in Bilski v. Kappos that Bernard Bilski's method for hedging risks of price fluctuations for commodities was an abstract idea that was ineligible for patent protection.' Four of the Justices would have gone further to hold that business methods were unpatentable subject matter (that is, not the kind of "process" for which patent protection was available). Although the Court as a whole was not persuaded that business methods should be deemed categorically ineligible for patent protection, ${ }^{3}$ in part because the term "business method" is difficult to define with precision, ${ }^{4}$ Justice Kennedy, writing the opinion of the Court for himself and three other Justices, recognized that "some business method patents raise special

' Bilski v. Kappos, 130 S. Ct. 3218, 3231 (2010).

${ }^{2}$ Id. at 3231-32 (Stevens, J., concurring) (Justice Stevens was joined by Justices Ginsburg, Breyer, and Sotomayor).

Id. at 3228 (majority opinion).

4 Id. (indicating that it was unclear "how far a prohibition on business method patents would reach, and whether it would exclude technologies for conducting a business more efficiently"). 
problems in terms of vagueness and suspect validity." After Bilski, these methods are likely to be deemed too abstract to be patentable.

Justice Kennedy went on to say that it was important to set a high bar for patentability of these kinds of inventions, for otherwise "patent examiners and courts could be flooded with claims that would put a chill on creative endeavor and dynamic change." ${ }^{6}$ To avoid this chilling effect on business innovation, a limiting principle was needed so that the U.S. Patent and Trademark Office (PTO) and the courts could determine which kinds of methods affecting business operations should be eligible (or not) for patent protection. Justice Kennedy pointed to the Court's prior rulings on the unpatentability of abstract ideas as likely to provide useful guidance for achieving this purpose. ${ }^{7}$ Drawing upon these precedents, the Court of Appeals for the Federal Circuit might, he thought, be able to "defin[e] a narrower category or class of patent applications that claim to instruct how business should be conducted, and then rule that the category is unpatentable because, for instance, it represents an attempt to patent abstract ideas," adding that "this conclusion might well be in accord with controlling precedent."

Although Justice Kennedy's opinion does not spell out with precision how to distinguish between unpatentable abstract ideas and patentable processes, it does offer some "clues" for drawing such distinctions that deserve attention going forward ${ }^{9}$ Part II of this Article discusses the clues we think are most likely to be useful to the PTO and the courts in developing a jurisprudence about abstractness as a disqualification from patent protection. Part III explains why, in light of these clues and in line with sound patent policy, business and service method innovations, while not categorically unpatentable, should still generally be excluded from patent protection as abstract ideas. Part IV provides further support for this approach by suggesting that taking the clues of unpatentability seriously may facilitate administrative and judicial efficiency in reviewing patent claims when assessing whether they satisfy patent subject matter rules.

${ }^{5}$ Id. at 3229. Justice Scalia did not join the subpart of Justice Kennedy's opinion in which this sentence appears. Id. at 3223.

'Id. at 3229. Justice Stevens' concurring opinion also emphasized that business method patenting could have chilling effects on innovation in that field. Id. at 325455 (Stevens, J., concurring).

Id. at 3229 (majority opinion).

${ }^{8} I d$.

9 The Court in Bilski drew the "clue" metaphor from the Court's decision in Gottschalk v. Benson, 409 U.S. 63, 70 (1972) and endorsed its use for assessing patentable subject matter in the future. Bilski, $130 \mathrm{~S}$. Ct. at 3226-27. 


\section{BILSKI DIRECTS US TO SEARCH FOR "CLUES" ABOUT ABSTRACTNESS}

In this Part, we mine the Bilski decision, the precedents on which it relies, as well as the Constitution, the Patent Act, and patent-related policies for clues that may aid in determining whether a claim is too abstract to qualify for patent protection, or is instead sufficiently concrete to be eligible for patenting, assuming other criteria for patentability are satisfied. While the rather amorphous clue-based approach to patent subject matter determinations may be frustrating for those looking for concise bright-line rules to patentability, the clue approach can be useful, especially when properly framed.

\section{A. Clues Derived from Bilski and Other Supreme Court Precedents}

Much like Sherlock Holmes or Harry Bosch, a patent examiner or a court searching for "clues" to patentability must both collect the clues and sift through them for a discernable pattern that leads to a sound conclusion. Often, it is easiest to begin with the most obvious clues and then move to those more nuanced or subtle. One clue readily discernable from the Court's Bilski decision is that the term "abstract idea" as a disqualification from patent protection is not limited to very high-level abstractions (e.g., the idea of cutting bread with a knife). For example, Bilski's first claim contained some relatively "concrete" elements, such as a commodity provider, a commodity, a price, and a market participant. ${ }^{10}$ And yet, the Court was unanimous in regarding it as too abstract to qualify for a patent."

A second clue comes from the Court's unanimous reaffirmation in Bilski that its decades-earlier ruling in Gottschalk $v$. Benson is still good law. ${ }^{12}$ Benson had once hoped to obtain a patent on a multi-step method of transforming binary coded decimals (BCD) to pure binary form. ${ }^{13}$ Under the patent subject matter standards used by the Federal Circuit for more than a decade prior to its ruling in In re Bilski, ${ }^{14}$ Benson would have

${ }^{10}$ Id. at 3223-24 (quoting claim 1 of the Bilski patent).

$"$ Id. at 3230-31. See also Interim Guidance for Determining Subject Matter Eligibility for Process Claims in View of Bilski v. Kappos, 75 Fed. Reg. 43922, 43924 (U.S. Pat. \& Trademark Office July 27, 2010) [hereinafter Interim Guidance] ("Moreover, the fact that the steps of a claim might occur in the 'real world' does not necessarily save it from a section 101 rejection. Thus, the Bilski claims were said to be drawn to an 'abstract idea' despite the fact that they included steps drawn to initiating transactions. The 'abstractness' is in the sense that there are no limitations as to the mechanism for entering into the transactions.").

12 Gottschalk v. Benson, 409 U.S. 63 (1972), sited with approval in Bilski, $130 \mathrm{~S}$. Ct. at 3230 , and id. at 3253 (Stevens, J., concurring).

13 Benson, 409 U.S. at 65.

${ }^{14}$ In re Bilski, 545 F.3d 943 (Fed. Cir. 2008) (en banc). In In re Bilski, the Federal Circuit abjured the useful, concrete, and tangible result test in favor of the "machine- 
been eligible for a patent because his method was capable of yielding "a useful, concrete, and tangible result.." ${ }^{15}$ Yet, the Supreme Court in Bilski could not have been clearer in expressing its view that the Benson method was too abstract to qualify for patent protection. The Court reiterated in Bilski, as it had in Benson, that no one can patent an idea. ${ }^{16}$ The practical effect of a patent on Benson's method would, however, have been the grant of a patent on an idea that would "wholly pre-empt [use of] the mathematical formula" or algorithm at issue. ${ }^{17}$

A second clue of unpatentability is, then, that mathematical formulae and algorithms as such, however novel or nonobvious they might be, are viewed by the Supreme Court as unpatentable abstractions. ${ }^{18}$ In fact, when analyzing the Bilski patent, Justice Kennedy wrote: "The concept of hedging, described in claim 1 and reduced to a mathematical formula in claim 4 , is an unpatentable abstract idea, just like the algorithms at issue in Benson and Flook."19 Therefore, claims that are capable of being reduced to mathematical formulae or algorithms, even if they are not written as such, can be held as abstract ideas based on this clue.

A third clue to abstractness as a disqualifier from patent protection is evident in Justice Breyer's concurring opinion in Bilski, which emphasizes several points on which the Justices were unanimous including the unpatentability of mental processes. ${ }^{20}$ Mathematical formulae are one subset of a much larger set of processes that can be carried out in a person's mind or with only the aid of pencil and paper. Many business methods are also susceptible to being carried out in a businessman's head (e.g., assessing the risk of lending money to clients with certain types of backgrounds); they too should be regarded as too abstract to

or-transformation" test. Id. at 959-60. See also infra notes 33-38 and accompanying text.

15 See, e.g., State St. Bank \& Trust Co. v. Signature Fin. Grp., Inc., 149 F.3d 1368, 1373 (Fed. Cir. 1998) (quoting In re Alappat, 33 F.3d 1526, 1544 (Fed. Cir. 1994)).

${ }_{16}$ Bilski, 130 S. Ct. at 3230 (quoting Benson, 409 U.S. at 67).

${ }^{17}$ Benson, 409 U.S. at 72, quoted in Bilski, 130 S. Ct. at 3230.

18 During oral argument, Justice Kennedy was quite skeptical of the idea that patents could be granted for important innovations in the insurance industry, such as actuarial tables. See Transcript of Oral Argument at 10-11, Bilski, 130 S. Ct. 3218 (2010) (No. 08-964) [hereinafter Transcript of Bilski Oral Argument].

19 Bilski, 130 S. Ct. at 3231 .

${ }^{20}$ Id. at 3257-58 (Breyer, J., concurring) (quoting Benson, 409 U.S. at 67); see also id. at 3226 (majority opinion) ("Concerns about attempts to call any form of human activity a 'process' can be met by making sure the claim meets the requirements of $\$ 101$."); Interim Guidance, supra note 11, at 43925 ("The nature of the article transformed, i.e., whether it is an object or substance, weighing toward eligibility, compared to a concept such as a contractual obligation or mental judgment, which would weigh against eligibility."), 43926 (listing "[m]ental activity" as an example of the patent-ineligible category of "general concepts"). 
qualify for patenting. ${ }^{21}$ Some methods whose patentability some Justices questioned during oral argument in the Bilski case were also mental process innovations. ${ }^{22}$

A fourth clue of unpatentability on abstractness grounds, also derived from Benson as well as from Bilski, is the wide range of applications in which a claimed method could be practiced. ${ }^{23}$ In Benson, the process claimed was "so abstract and sweeping as to cover both known and unknown uses of the BCD to pure binary conversion. The end use may (1) vary from the operation of a train to verification of drivers' licenses to researching the law books for precedents and (2) be performed through any existing machinery or future-devised machinery or without any apparatus. ${ }^{24}$ This affected the Court's view of it as too abstract to qualify for patenting. In Bilski, Justice Kennedy wrote: "Allowing petitioners to patent risk hedging would pre-empt use of this approach in all fields, and would effectively grant a monopoly over an abstract idea." ${ }^{25}$ Again, the wide-ranging impact of the claim was a clue to being too abstract.

A fifth clue of unpatentability on abstractness grounds would seem to be processes that involve representing or transforming data from one form to another. Recall that the method at issue in Benson transformed the representation of data from BCD to pure binary form. It did not matter to the Court that this transformation could take place through the use of a programmed digital computer; the method was simply unpatentable. ${ }^{26}$ Along similar lines, several Justices expressed skepticism about the patentability of data representation and communication during oral argument in the Bilski case. ${ }^{27}$

A sixth clue of unpatentability on abstractness grounds can be found in Parker v. Flook, ${ }^{28}$ which the Court in Bilski also reaffirmed as a sound

${ }^{21}$ See, e.g., Brief for Kevin Emerson Collins as Amicus Curiae in Support of Neither Party, In re Bilski, 545 F.3d 943 (Fed. Cir. 2008) (No. 2007-1130) (en banc), available at http://www.patentlyo.com/patent/bilski.collins.pdf.

${ }^{22}$ See, e.g., Transcript of Bilski Oral Argument, supra note 18, at 5-7 (methods of resisting a corporate takeover, of choosing a jury, and of avoiding taxes).

${ }^{23}$ See Interim Guidance, supra note 11, at 43925 ("Application of a law of nature having broad applicability across many fields of endeavor weighs against eligibility ....").

${ }^{24}$ Benson, 409 U.S. at 68.

${ }_{25}$ Bilski, $130 \mathrm{~S}$. Ct. at 3231 .

${ }^{26}$ One of the claims in Benson was for the method carried out through the use of a general purpose computer. Yet, the Court regarded this method to be equally unpatentable as the claim that did not specify the use of an apparatus. Benson, 409 U.S. at 65, 68-72. During oral argument in Bilski, several Justices were openly skeptical of the idea that merely computerizing an abstract process would render it patentable. See, e.g., Transcript of Bilski Oral Argument, supra note 18, at 30-36.

${ }^{27}$ Transcript of Bilski Oral Argument, supra note 18, at 9 (questioning the patentability of a method of teaching antitrust), 16 (questioning the patentability of a method of horse training), 22 (questioning the patentability of alphabets).

${ }^{28} 437$ U.S. 584 (1978). 
precedent. ${ }^{29}$ In Flook, the claim was for an improved method of calculating alarm limits for a catalytic conversion process. ${ }^{30}$ Although the claim contained a step that was to be performed after the calculations had yielded a solution, the Court characterized this step as insignificant "post-solution activity" which could not render the claimed method patentable subject matter. ${ }^{31}$ Flook also made clear that mere field-of-use limitations would not overcome the abstractness objection to the patenting of a mathematical process. ${ }^{32}$ The Court in Bilski endorsed Flook as another source of guidance for the unpatentability of abstract methods. $^{33}$

While we have thus far emphasized the clues that tip against patentability, the Court recognized that some clues will point to the existence of sufficient concreteness to support patentability. The most important of the clues identified in Bilski lies in the "machine-ortransformation" (MoT) test. ${ }^{34}$ The Federal Circuit articulated this test in its Bilski decision, saying that a claimed process is eligible for patent protection if: "( 1 ) it is tied to a particular machine or apparatus, or (2) it transforms a particular article into a different state or thing., ${ }^{, 35}$ Although the Supreme Court rejected the Federal Circuit's endorsement of MoT as the "sole test" of patentability, it recognized MoT as "an important and useful clue" in patent subject matter determinations. ${ }^{36}$ Diamond v. Diehr is an example of a method that was concrete enough to be patentable because the programmed computer's calculations in that case were elements of a process for transforming rubber from one physical state to another. ${ }^{37}$ This method was also tied to a specific machine.

\section{B. The Constitution's Emphasis on Promoting Progress Provides Another Clue to Determining Abstractness}

In addition to the clues one can find in the Supreme Court's jurisprudence, one can also look to other sources of authority for

${ }^{29}$ Bilski, 130 S. Ct. at $3230-31$.

so Flook, 437 U.S. at 585.

${ }^{31} I d$. at 590, construed in Diamond v. Diehr, 450 U.S. 175, 191 (1981) ("insignificant postsolution activity will not transform an unpatentable principle into a patentable process").

${ }_{32}$ Diehr, 450 U.S. at 191-92 (discussing Flook).

${ }^{33}$ Bilski, 130 S. Ct. at 3226.

${ }^{34}$ See id. at 3224-28.

${ }^{35}$ In re Bilski, 545 F.3d 943, 954 (Fed. Cir. 2008) (en banc).

${ }^{36}$ Bilski, 130 S. Ct. at 3226.

${ }^{37}$ Diehr, 450 U.S. at 184

38 Id. at 177-78 (describing a process by which a specific digital computer sends a signal to a specific rubber pressing machine to open at a specific time). We agree with the PTO's Interim Guidance notice which indicates that the more a process is tied to a specific machine, rather than just a general purpose computer, the more likely it is to recite patentable subject matter. Interim Guidance, supra note 11, at 43925 . 
guidance on determining what constitutes an abstract idea. While nothing in the text of the Constitution provides a direct explanation as to why "abstractions" are unpatentable, the patent clause and its context provide at least one "clue" for how courts should assess abstractness. As all who study patent law know, the Constitution speaks directly of the purpose of patent law, to promote the progress of the useful arts. ${ }^{39}$ The relationship between this purpose, $\S 101$, and the abstract idea limitation was reinforced throughout all three Bilski opinions as well as the Court's prior $§ 101$ case law. ${ }^{40}$

Thus, the principal constitutional clue to patentability is the progress of the useful arts. ${ }^{41}$ To promote such progress, inventions need to be concrete, not abstract; they must also be specific, not general. Progress must be capable of being measured; it must have direct benefits that can be defined. Abstract ideas, on the other hand, lack specific benefits that are measurable. Abstract ideas are also, as the Supreme Court has repeatedly recognized, "part of the storehouse of knowledge of all men... [which must be] free to all men and reserved exclusively to none," as well as "the basic tools of scientific and technological work" whose patent-free status contributes to the very progress that the Constitution aims to bring about. ${ }^{43}$

The constitutional focus on progress of the useful arts is consistent with the holding in Bilski. There, the Court found the claim at issue to be abstract in part because it covered a "basic concept" and a "fundamental economic practice long prevalent in our system of commerce and taught in any introductory finance class. " ${ }^{44}$ It also held that Bilski's claim was unpatentable because it could be "reduced to a mathematical formula." 45 In other words, stating the basic concept or fundamental economic practice did not promote any particular progress; rather, particular

${ }^{39}$ See U.S. ConST. art. I, $\S 8, \mathrm{cl} .8$ (the purpose of patents is to "promote the Progress of . . useful Arts.”); KSR Int'l Co. v. Teleflex Inc., 550 U.S. 398, 427 (2007) (" $[T]$ he results of ordinary innovation are not the subject of exclusive rights under the patent laws. Were it otherwise patents might stifle, rather than promote, the progress of useful arts.").

Bilski, 130 S. Ct. at 3226-31. See also id. at 3238-47 (Stevens, J., concurring); id. at 3258-59 (Breyer, J., concurring); Bonito Boats, Inc. v. Thunder Craft Boats, Inc., 489 U.S. 141, 150-51 (1989); Diehr, 450 U.S. at 192 (processes are patentable when the claim "is performing a function which the patent laws were designed to protect"); Graham v. John Deere Co. of Kan. City, 383 U.S. 1, 9-11 (1966).

${ }^{4}$ See Bilski, $130 \mathrm{~S}$. Ct. at 3253 (Stevens, J., concurring) ("The Court has kept this 'constitutional standard' in mind when deciding what is patentable subject matter under $\S 101 . ")$.

12 Funk Bros. Seed Co. v. Kalo Inoculant Co., 333 U.S. 127, 130 (1948), quoted in Bilski, $130 \mathrm{~S}$. Ct. at 3225.

4s Benson, 409 U.S. at 67.

14 Bilski, 130 S. Ct. at 3231 (quoting In re Bilski, 545 F.3d 943, 1013 (Fed. Cir. 2008) (en banc) (Rader, J., dissenting)).

${ }^{45}$ Id. 
implementations of an idea are the methods that promote progress in a constitutional sense and thus a clue to concreteness.

\section{The Patent Act's Emphasis on Machines, Manufactures, and Compositions of Matter also Provides Clues to Distinguishing Abstract Ideas from Concrete \\ Processes}

The history and structure of the Patent Act also provide clues as to what is, and is not, an abstract process. As the Supreme Court has noted, Congress did not authorize patenting of "any [process] under the sun." In $\$ 101$, Congress expressly limited patenting to four types of inventions-processes, machines, manufactures, and compositions of matter-leaving other forms of innovation in the public domain where freedom to innovate is prevalent. ${ }^{48}$

While the word "abstract" does not appear in the Patent Act, the Court in Bilski connects the concept of abstractness as a limit on patent subject matter with the statutorily-eligible category of "processes." Thus, the meaning of "abstract" in relation to $\$ 101$ is a question of statutory interpretation because, in essence, the Bilski Court interpreted the word "process" to mean "non-abstract processes." Under the doctrine of noscitur a sociis, courts may look to surrounding terms to inform the meaning of any individual term in a statute. ${ }^{49}$ Here, the word "process" is side-by-side with machine, manufacture, and composition of matter, and cannot be understood in isolation from its statutory companions. ${ }^{50}$ Thus,

${ }^{46}$ See id. at 3230 ("Diehr explained that while an abstract idea, law of nature, or mathematical formula could not be patented, 'an application of a law of nature or mathematical formula to a known structure or process may well be deserving of patent protection." (quoting Diamond v. Diehr, 450 U.S. 175, 187 (1981)). See also id. at 3258 (Breyer, J., concurring) (noting that abstract ideas are not patentable because allowing individuals to patent these fundamental principles would "'wholly pre-empt' the public's access to the 'basic tools of scientific and technological work[,]" thus inhibiting the overall progress of the useful arts (quoting Benson, 409 U.S. at 67, 72)); Diehr, 450 U.S. at 184 (noting that machines must be "particular" machines under a MoT analysis).

${ }^{47}$ Bilski, 130 S. Ct. at 3248 (Stevens, J., concurring).

4835 U.S.C. $\$ 101$ (2006). See Diehr, 450 U.S. at 185 (noting that while each individual term of the four is to be construed broadly, "every discovery is not embraced within the statutory terms" (emphasis added)); Parker v. Flook, 437 U.S. 584, 588-89 (1978).

${ }^{49}$ See United States v. Williams, 128 S. Ct. 1830, 1839 (2008) ("a word is given more precise content by the neighboring words with which it is associated" (citing Jarecki v. G.D. Searle \& Co., 367 U.S. 303, 307 (1961)); Babbitt v. Sweet Home Chapter of Cmtys. for a Great Or., 515 U.S. 687, 687 (1995) (noting that "a word is known by the company it keeps").

50 See 35 U.S.C. $\$ 101$. See also 35 U.S.C. $\$ 100(\mathrm{~b})$ (2006) (defining process as including "a new use of a known process, machine, manufacture, composition of matter, or material."). It is worth noting that the Court in Bilski did not use noscitur a sociis primarily because it found the word "process" defined in the Act under $\S 100$ (b). However, since we are looking to define "abstract," which does not appear in the statute, we do not anticipate any conflict in the courts over application of this 
these three words-machines, manufactures, and compositions of matter-are themselves clues as to concreteness, and association with them would weigh against abstractness. ${ }^{51}$ When combined with the constitutional clue of promoting progress, improvement or advancement of machines, manufactures, and compositions of matter provides an even stronger clue that a process is concrete and not abstract. ${ }^{52}$

The clues of "promoting progress" and the other categories of invention in $\S 101$ are also consistent with the history of the Patent Act. ${ }^{53}$ When Congress last amended $\S 101$ in 1952, it did so at the height of the industrial age, an age where science and engineering focused on machines, manufacturing, and the creation of compositions of matter. These were the technologies that were patentable at the time, along with the processes of creating them. ${ }^{54}$

Not surprisingly, the prevailing understanding at that time was also that processes that lacked specific application to machines, manufacturing, or compositions of matter-such as processes for doing business, practicing law, arbitrating disputes, raising money for charity, or writing novels-were unpatentable..$^{55}$ When Congress amended $\S 101$ in 1952, it merely ratified this prevailing understanding. ${ }^{56}$ As Judge Giles Rich, one of the principle drafters of the 1952 Act, explained soon after the act was passed:

canon. See Bilski, $130 \mathrm{~S}$. Ct. at 3226 ("ambiguous [terms in statutes] may be given more precise content by the neighboring words with which it is associated" (quoting United States v. Stevens, 130 S. Ct. 1577, 1588 (2010)).

${ }^{51}$ The MoT test is clearly one instance of this, as "machine" appears in $\S 101.35$ U.S.C. $\$ 101$.

${ }_{52}$ See Interim Guidance, supra note 11, at 43925 ("Integral use of a machine or apparatus to achieve performance of the method weighs toward eligibility, as compared to where the machine or apparatus is merely an object on which the method operates, which weighs against eligibility."). See also id. (noting that the use of a machine or apparatus that contributes only "nominally or insignificantly to the execution of the claimed method" would weigh against patent eligibility).

${ }^{53}$ As the Supreme Court has held, "a page of history is worth a volume of logic." Eldred v. Ashcroft, 537 U.S. 186, 200 (2003) (quoting N.Y. Trust Co. v. Eisner, 256 U.S. 345,349 (1921)).

${ }_{54}$ Utilizing the other inventive categories of $\S 101$ as clues to patentability also comports with the historical origin of "process," which the Court has held is synonymous with "art." Diamond v. Diehr, 450 U.S. 175, 182-84 (1981). As others have pointed out, ' $[t]$ he term 'useful arts,' as used in the Constitution ... is best represented in modern language by the word 'technology." Karl B. Lutz, Patents and Science: A Clarification of the Patent Clause of the U.S. Constitution, 18 GEO. WASH. L. REV. 50, 54 (1949).

${ }_{55}$ See Bilski, $130 \mathrm{~S}$. Ct. at 3239-46 (Stevens, J., concurring); In re Bilski, 545 F.3d 943, 1001-02 (Fed. Cir. 2008) (en banc) (Mayer, J., dissenting) (collecting cases that rejected patenting of non-technological methods).

${ }^{56}$ See Nationwide Mut. Ins. Co. v. Darden, 503 U.S. 318, 322 (1992) (holding that where no contrary indication is present, courts presume Congress intended to ratify, rather than overturn, the prevailing legal understanding at the time). 
Of course, not every kind of an invention can be patented. Invaluable though it may be to individuals, the public, and national defense, the invention of a more effective organization of the materials in, and the techniques of teaching a course in physics, chemistry, or Russian is not a patentable invention because it is outside of the enumerated categories of "process, machine, manufacture, or composition of matter, or any new and useful improvement thereof." Also outside that group is one of the greatest inventions of our times, the diaper service.

What all of Judge Rich's examples (the diaper service, a more effective organizational approach, and improved techniques for teaching courses) share in common is that they are abstract in nature. Even if they may use concrete manufactures, compositions of matter, or machines (a washing machine and detergent in the case of a diaper service, telephones in implementing an improved method of organization, and a blackboard and chalk in teaching) the processes themselves are not patentable because their association with these concrete components does not involve a specific concrete application of the process to improve or advance a particular machine, manufacture, or composition of matter. $^{58}$

This is also consistent with the function of the patent laws historically, which was not only to protect new machines, manufactures, and compositions of matter, but also the "working or making of any manner of new manufactures within this realm." ${ }^{59}$ One example of such workings and makings is James Watt's famous 1769 patent on a "[m]ethod of diminishing the consumption of fuel in [steam]-engines." These kinds of processes-the working and making of machines and manufactures-advanced these technological subject matters, advancing the useful arts. ${ }^{61}$ Thus, each time the Supreme Court has historically

${ }^{57}$ Giles S. Rich, Principles of Patentability, 28 GEO. WASH. L. REV. 393, 393-94 (1960) (quoting 35 U.S.C. $\$ 101$ ).

${ }_{58}$ This same approach can be used to explain why several of the justices at the Bilski oral argument expressed skepticism toward patents on such methods as speed dating and an improved method of teaching antitrust law, even though these methods would inevitably involve concrete objects such as electronic timers, laptops, visual projectors, and microphones. See Transcript of Bilski Oral Argument, supra note 18 , at $7-9$.

${ }^{59}$ In re Bilski, 545 F.3d at 968 (Dyk, J., concurring) (emphasis omitted) (quoting Statute of Monopolies, 1623, 21 Jac. 1, c. 3 (Eng.)).

${ }^{60} I d$. at 970 (alterations in original) (emphasis and citation omitted).

${ }^{61}$ See Tilghman v. Proctor, 102 U.S. 707, 722 (1880) (manufacturing processes are within the meaning of the term "art"); Cochrane v. Deener, 94 U.S. 780, 788 (1876) (finding patentable processes to be "a mode of treatment of certain materials to produce a given result"); Corning v. Burden, 56 U.S. (15 How.) 252, 267-68 (1853) (noting patentable processes must produce a certain effect or manufacture by means of "chemical action, by the operation or application of some element or power of nature, or of one substance to another"). See also Bilski v. Kappos, $130 \mathrm{~S}$. Ct. 3218, 3240 (2010) (Stevens, J., concurring) (noting the emphasis in the English Statute of 
spoken to the patentability of processes, it has reinforced that valid ones should advance the development, understanding, or application of a machine, manufacture, or composition of matter.

\section{THE ABSTRACTNESS "CLUES" AND SOUND PATENT POLICY SUGGEST THAT BUSINESS AND SERVICE PROCESSES ARE STILL OFTEN UNPATENTABLE}

The clues discussed above are important considerations when courts or the PTO consider the patentability of all types of processes. However, they are particularly important when considering the patentability of business and service processes, not only because these types of processes have not been historically recognized as patentable ${ }^{69}$ but also because heightened scrutiny of patents in these industries comports with sound patent policy. While the Court in Bilski rejected a categorical prohibition on such processes being patentable, all nine Justices recognized the dangers of allowing patents in these areas. ${ }^{64}$ Thus, it is particularly important for the PTO and the Court to use these clues to scrutinize patent applications on such processes.

In particular, strict application of these clues for ferretting out abstract ideas from patentable business and service processes protects the public interest for four reasons: first, there are generally sufficient incentives for innovation already in these industries and thus less patent protection is necessary; second, the research and development (R\&D) costs that typically justify patent protection are lower for business and service processes; third, business and service innovation is far more diffuse and collaborative; and fourth, over-extending patent protection to business and service industries would disrupt settled expectations and impose substantial additional costs on investors and innovators. Below, we discuss each of these in more detail and map them to several of the clues above.

Monopolies on allowing process patents for the "mode, method, or way of manufacturing" (citation omitted)).

${ }^{62}$ See Jacobs v. Baker, 74 U.S. (7 Wall.) 295, 297 (1868) ("But if the subjectmatter be neither a machine nor a manufacture, nor a composition of matter, then ... it must be an art, for there can be no valid patent except it be for a thing made, or for the art or process of making a thing." (quoting GEORGE TICKNOR CURTIS, A TREATISE ON THE LAW OF PATENTS FOR USEFUL INVENTIONS IN THE UNITED STATES OF AMERICA 91 (2nd ed. 1854))); Corning, 56 U.S. at 267 (a patentable art includes "methods, or operations ... called processes" such as the "arts of tanning, dyeing, making water-proof cloth, vulcanizing India rubber, [and] smelting ores").

63 See Bilski, 130 S. Ct. at 3237-47 (Stevens, J., concurring).

${ }^{64} I d$. at 3230 (majority opinion). 


\section{A. Patent Protection Is Generally Unnecessary to Promote Innovation in Business and Service Processes}

" $[F]$ rom the outset, federal patent law has been about the difficult business 'of drawing a line between the things which are worth to the public the embarrassment of an exclusive patent, and those which are not." ${ }^{\prime 5}$ Patents on business and service methods will often fall in the latter category. Prior to the Federal Circuit's ill-conceived State Street $B a n k^{66}$ decision, business and service innovations thrived in the United States without patent protection. ${ }^{67}$

Service industries may use more technology today, such as programmed computers, than they did in the past, but patents are rarely sought or needed to encourage innovation for new business models or services. $^{68}$ In a recent survey of over 1,300 high technology entrepreneurs, close to three-fourths of software and e-commerce startups (which are among the most technologically-driven participants in modern business and service industries) reported that they do not own patents and have not applied for them, compared with less than a quarter of similarly-situated biotechnology and medical device companies. ${ }^{69}$ Software and e-commerce companies report also seeking patent protection almost five times less frequently than computer hardware startups. $^{70}$ Thus, even in technology-driven business and service industries, patent protection is largely disfavored as a source of incentives for innovation; for non-technological businesses and services, it would provide even less. Instead, business and service-oriented industries rely

${ }^{65}$ See Bonito Boats, Inc. v. Thunder Craft Boats, Inc., 489 U.S. 141, 148 (1989) (quoting 13 THOMAS JEFFERSON, THE WRITINGS OF THOMAS JEFFERSON 335 (Andrew A. Lipscomb ed., Thomas Jefferson Mem'l Ass'n 1903)).

${ }^{66}$ State Street Bank \& Trust Co. v. Signature Fin. Group, Inc., 149 F.3d 1368 (Fed Cir. 1998).

${ }^{67}$ See Leo J. Raskind, The State Street Bank Decision: The Bad Business of Unlimited Patent Protection for Methods of Doing Business, 10 Fordham InTELL. Prop. Media \& ENT. L.J. 61, 93 (1999) (citing the rapid growth of fast food restaurants, self-service gasoline stations, quick oil change facilities, ATMs, and alternative long-distance telephone services as examples of business innovations that occurred without patent incentives).

${ }_{68}^{68}$ Abstractness of many software innovations for which patents may be sought has contributed to difficulties in patents performing the important function of defining the metes and bounds of patent claims. See, e.g., James BESSEN \& MichaEL J. Meurer, Patent Failure: How Judges, Bureaucrats, and LaWMers Put INNOVATORS at RISK 187-214 (2008).

${ }^{69}$ Stuart J.H. Graham et al., High Technology Entrepreneurs and the Patent System: Results of the 2008 Berkeley Patent Survey, 24 BERKELEY TECH. L.J. 1255, 1255, 1277 (2009).

${ }^{70} I d$. at 1277,1283 (reporting patents offer "relatively mixed to weak incentives to engage in innovation" in these areas). See also id. at 1286 (reporting that patents provide between "slight" and "no incentive at all" for internal process innovations), 1290-92 (reporting "patenting" as the least important incentive for innovation and maintaining competitive advantages). 
upon a wide variety of other incentives that promote innovation. These include first-mover advantages, complementary assets, trade secrets, and customer loyalty. $^{71}$

First-mover advantages are particularly prevalent in business and service innovation because they provide competitive advantages that cannot be copied, such as consumer brand loyalty and heightened switching costs. ${ }^{72}$ For example, in frequent flyer programs, the first airline to convince a customer to invest often remains the primary program for that customer-despite robust competition from other airlines-because of the customer's substantial investment in the program and the high switching costs associated with starting over. ${ }^{79}$ Such programs also face little danger of the kind of copying and free-riding that patents are meant to prevent. One airline can copy the general rules and structure of another's program, but the true value and competitive advantage are in the customer's investment and loyalty to their account and achieving the benefits it offers. $^{74}$ At the same time, competition keeps the pressure on airlines to continue innovating and responding to consumer demand, so that the switching costs do not become worthwhile to the customer. Patent incentives, on the other hand, would not encourage such competition-if customer-friendly programs like frequent flying were patentable, then the first airline would gain the spoils, and other airlines would be prevented from innovating and competing. ${ }^{75}$

${ }^{7} I d$. at 1290-92 (noting that first-mover advantages, complementary assets, and trade secrecy are the most important strategies for securing competitive advantages among software and e-commerce startups), 1292 (noting, in summary, that software and internet startups strongly prefer first-mover advantages to patents when seeking incentives to innovate). See also Bilski v. Kappos, 130 S. Ct. 3218, 3254 (2010) (Stevens, J., concurring).

72 See Stefania Fusco, Is the Use of Patents Promoting the Creation of New Types of Securities?, 25 SANTA ClaRA COMPUTER \& HigH TECH. L.J. 243, 256 (2009) (citing Peter Tufano, Financial Innovation and First-Mover Advantages, 25 J. FIN. ECON. 213, 214-15, 234-35 (1989)). See also ADAM B. JAFFE \& JOSH LERNER, INNOVATION AND ITS Discontents: How OUR BROKEN PATENT SYSTEM IS ENDANGERING INNOVATION AND PROGRESS, AND WHAT TO DO ABOUT IT 47 (2004) (discussing brand loyalty and consumer learning curves as strong first-mover advantages over competitors); Wesley M. Cohen, Richard R. Nelson \& John P. Walsh, Protecting Their Intellectual Assets: Appropriability Conditions and Why U.S. Manufacturing Firms Patent (or Not) 28 (Nat'l Bureau of Econ. Research, Working Paper No. 7552, 2000), available at http://www.nber.org/papers/w7552.pdf; Helios Herrera \& Enrique Schroth, Profitable Innovation Without Patent Protection: The Case of Derivatives 6 (Centro de Investigación Económica, Working Paper No. 03-02, 2003), available at http://ftp.itam.mx/pub/academico/inves/herrera/03-02.pdf.

${ }_{73}$ Fredrik Carlsson \& Åsa Löfgren, Airline Choice, Switching Costs and Frequent Flyer Programmes, 38 APPLIED ECON. 1469, 1469-70 (2006).

74 Id. at 1474.

75 See also Fred Smith \& Brian Dumaine, How I Delivered the Goods, ForTUne SMALL Bus., Oct. 1, 2002, at 28, available at http://money.cnn.com/magazines/fsb /fsb_archive/2002/10/01/330568/index.htm (describing Federal Express's firstmover advantages). 
Patent monopolies are equally unnecessary for many service-driven Internet companies such as Google, Twitter, YouTube, and Facebook. These companies have few, if any, patents and almost never enforce them. ${ }^{76}$ Yet they command significant market shares through their firstmover statuses, innovation-driven cultures, technological and data lockins, and emphasis on customer service and loyalty.

In addition to first-mover advantages, business and service industries can use complementary assets to secure their market positions and recoup their investment. Lawyers who provide high quality corporate services to clients may also attract those clients when additional matters such as litigation arise. A good doctor will attract the family and friends of patients. A good plumber will attract repeat business for additional household problems. These business advantages-and the innovation and quality required to maintain them-are based on loyalty and reputation, not patent incentives. ${ }^{78}$

Other non-patent incentives for innovation in the business and service industries include ongoing professional development and expertise (e.g., the more one performs and improves one's service, the higher quality performance one offers) and customization (e.g., solving a particular client's problem often provides information on the client and the problem that competitors may lack). ${ }^{79}$

Rather than the repetition of identical items, which is characteristic of manufacturing and quite vulnerable to copying, it is the individualized

${ }^{76}$ See generally Graham et al., supra note 69.

77 See Sara Kehaulani Goo, Building a 'Googley' Workforce, WaSH. PoST, Oct. 21, 2006, available at http://www.washingtonpost.com/wp-dyn/content/article/2006/10 /20/AR2006102001461.html. See also JONATHAN ZITTRAIN, THE FUTURE OF THE INTERNET-AND HOW TO STOP IT 102-03 (2008) (discussing platform lock-in).

${ }^{78}$ See generally Pamela Samuelson, What Effects Do Legal Rules Have on Service Innovation?, in HANDBOOK OF SERVICE SCIENCE 603 (Paul P. Maglio, Cheryl A. Kieliszewski \& James Spohrer eds., 2010), available at http://ssrn.com /abstract=1421946; Hearing on Issues Relating to the Patenting of Tax Advice Before the Subcomm. on Select Revenue Measures of the H. Comm. on Ways Eे Means, 109th Cong. 77 (2006) (statement of Ellen Aprill, Associate Dean of Academic Programs, Professor of Law, and John E. Anderson Chair of Tax Law, Loyola Law School, Los Angeles, California) (noting that existing economic incentives for tax planning already provide ample inducement for the development, promotion, and implementation of new strategies). See also generally Eric Goldman, Online Word of Mouth and Its Implications for Trademark Law, in TRADEMARK LAW AND THEORY: A HANDBOOK OF Contemporary Research 404, 410 (Graeme B. Dinwoodie \& Mark D. Janis eds., 2008)

79 See Michael Polany, The Tacit Dimension 72-89 (1966) (discussing the highly detailed, often context-specific knowledge actually required to do a complex job well); Robert P. Merges, The Uninvited Guest: Patents on Wall Street 10-11 (UC Berkeley Pub. Law \& Legal Theory Research Paper Series, Research Paper No. 126, 2003), available at http://ssrn.com/abstract $=410900$ (citing Tufano, supra note 72, at 235) (reporting a bankers' view that innovation is the best way to advertise expertise). 
qualities of the service marketplace that provide competitive advantage. ${ }^{80}$ Put another way, the provision of services cannot be duplicated in the same way that a product or device can be copied; thus, the classic freeriding problem in patent-intensive industries is avoided. ${ }^{81}$

The characteristics and practices in business and service professions we have identified here provide policy reasons for heeding the abstractness clues that will frequently be evident in applications seeking patents for business and service innovations, that patent protection is unnecessary in many, if not most, cases to provide incentive for innovation in these fields. This links directly to the constitutional and statutory clues noted above as patents on such processes would generally not promote additional progress in these areas, and certainly not the progress of particular machines, manufactures, or compositions of matter.

\section{B. By Their Nature, Business and Service Innovators Have Not Needed Patent Incentives Because They Have Had Less Intensive RE'D Costs than Technological Innovators}

Patents should only be granted to those inventions "which would not be disclosed or devised but for the inducement of a patent." $\mathrm{R} \& \mathrm{D}$ costs of technology innovation, coupled with low costs of copying, are a major reason why patent incentives help to promote innovation in technology-intensive industries. ${ }^{83}$

Business and service innovations, however, do not typically require the substantial up-front investments-for example, engineering teams, $\mathrm{R} \& \mathrm{D}$ labs, expensive equipment, and/or clinical trials-that undergird the perceived need for patent protection in manufacturing industries. ${ }^{84}$ Without high up-front costs to recoup, there is simply less need to protect business and service innovations with patents. Lower $R \& D$ costs also allow innovators to recoup their investments more quickly without the need of

80 See Frances X. Frei, Breaking the Trade-Off Between Efficiency and Service, HARV. Bus. REv., Nov. 2006, at 93, 93-101; Conrad Lashley, Towards an Understanding of Employee Empowerment in Hospitality Services, 7 INT'L J. CONTEMP. HosPITALITY MGMT. 27, 27-32 (1995).

81 See Merges, supra note 79, at 10-11 (citing Robin Cowan, Paul A. David \& Dominique Foray, The Explicit Economics of Knowledge Codification and Tacitness, 9 INDUS. \& CORP. CHANGE 211, 211-53 (2000)) (noting that customized knowledge is difficult to codify and even harder to transfer from one person to another).

${ }^{82}$ Graham v. John Deere Co. of Kan. City, 383 U.S. 1, 11 (1966).

S9 Se BESSEN \& MEURER, supra note 68, at 216.

${ }^{84}$ See Bilski v. Kappos, 130 S. Ct. 3218, 3254 (2010) (Stevens, J., concurring) (noting that business innovation generally does not require the same enormous costs in terms of time, research, and development as more traditional technological innovation); Andrew A. Schwartz, The Patent Office Meets the Poison Pill: Why Legal Methods Cannot Be Patented, 20 HARv. J.L. \& TECH. 333, 369 (2007) (noting that "[ $\mathrm{t}]$ here is no need to buy or build expensive machinery or run tests on prototypes" in service professions like the practice of law). 
20 years of patent protection, thus making competitive advantages such as first-mover adequate for cost recovery.

In light of these lower $R \& D$ costs, the constitutional and statutory clues we have noted strongly suggest that where there is no economic need for patent protection to promote specific innovations-especially innovations related to machines, manufactures, or compositions of matter-the PTO and the courts should heavily scrutinize process patent applications in order to ferret out abstract ideas from receiving protection. Specifically, where R\&D costs are low, the legal and administrative gatekeepers for patenting should take particular care to consider the Flook clues of insignificant post-solution activity and mere field-of-use limitations to ensure against unnecessary protection of abstract ideas. Where a patent applicant has not invested significant R\&D in the tangible elements of her claim (such as the use of a telephone as part of a business process), the Flook clues are more likely to apply.

\section{Business and Service Innovations Are Often More Diffuse and Collaborative and Thus Fall Outside of the Classic Patent "Reward" Paradigm}

Classic patent economics presumes that the costs of innovation will be efficiently internalized within single firms or individuals, and innovators will need exclusive rights to encourage investment and recoup those costs. ${ }^{85}$ In most technological industries such as pharmaceutical, electronics, and manufacturing firms, single entities bear the full $R \& D$ costs of initial development, refinement, production, maintenance, and ongoing innovation. These R\&D costs are typically passed on to consumers as part of the price of specific products, but consumers have typically played a very minimal and indirect role in the actual practice of research and development.

In service and business industries, however, such economics do not map easily or appropriately because innovation is often derived from collaboration with customers. $^{86}$ For example, professional service innovations are often discovered and developed on-site with clients at their place of business or as a result of a client's own innovative approaches to the problem the provider is helping to solve. Even when the subject matter is technological, consumers frequently innovate new processes and then voluntarily transfer that knowledge back to the producers of the technology without patenting them and at no charge. ${ }^{87}$

85 BESSEN \& MEURER, supra note 68, at 216.

${ }^{86}$ Mary Jo Bittner, Stephen W. Brown \& Matthew L. Meuter, Technology Infusion in Service Encounters, 28 J. ACAD. MARKETING SCI. 138, 138-49 (2000).

${ }^{87}$ See Jeroen P.J. de Jong \& Eric von Hippel, Measuring User Innovation in Dutch High Tech SMEs: Frequency, Nature and Transfer to Producers 3-4 (MIT Sloan Sch. of Mgmt., Working Paper No. 472409, 2009), available at http://ssrn.com /abstract=1352496; Fred Gault \& Eric von Hippel, The Prevalence of User Innovation and Free Innovation Transfers: Implications for Statistical Indicators and Innovation Policy 2, 4, 19 (MIT Sloan Sch. of Mgmt., Working Paper No. 4722-09, 2009), available at 
Thus, patents for business and service innovation may often fail to allocate rewards appropriately and may potentially bar some userinnovators from practicing the very methods they underwrote or to which they contributed. The constitutional and statutory clues discussed above help ensure that users and customers can continue to innovate in general areas of process improvement without fear that a single actor will gain patent protection for the basic concepts or wide-ranging applications of processes in these areas. ${ }^{88}$

\section{Extensive Patent Protection on Business and Services Would Disrupt Settled Expectations and Impose Substantial Additional Costs on Innovators and Investors}

Setting aside lack of necessity and inapplicability, extensive patenting of business and service processes would also actively hurt innovation and disrupt settled expectations. ${ }^{89}$ As the Supreme Court observed, " $[\mathrm{t}]$ he balance between the interest in motivating innovation and enlightenment by rewarding invention with patent protection on the one hand, and the interest in avoiding monopolies that unnecessarily stifle competition on the other, has been a feature of the federal patent laws since their inception." ${ }^{, 0}$

Business and service industries attract a high proportion of individual entrepreneurs, small businesses, and other so-called "startups." These entrepreneurs already face disproportional regulatory costs that inhibit their advancement in the marketplace vis-à-vis larger firms. ${ }^{92}$ Imposing a new layer of significant additional costs for patent searches, legal counsel, litigation defense, and license negotiation would

http://ssrn.com/abstract=1337232. See also ERIC VON HIPPEL, THE SOURCES OF InNovation 25-26 (1988); Yochai Benkler, Coase's Penguin, or, Linux and The Nature of the Firm, 112 YALE L.J. 369, 372 (2002).

${ }^{8 s}$ See supra notes $23-25$ and accompanying text (wide-ranging application and basic concept clues).

${ }^{89}$ See Festo Corp. v. Shoketsu Kinzoku Kogyo Kabushiki Co., 535 U.S. 722, 739 (2002) (noting that courts should be cautious not to disrupt settled expectations when deciding patent cases).

${ }^{90}$ Pfaff v. Wells Elecs., Inc., 525 U.S. 55, 63 (1998).

${ }^{91}$ See Small Bus. Admin., Office of Advocacy, The Small Business Economy: A REPORT TO THE PRESIDENT 20-21 (2009), available at http://www.sba.gov/advo /research/sb_econ2990.pdf (showing $41.88 \%$ of new financial services are small businesses and $43.88 \%$ of new professional and business services are small businesses). See also Robert W. FAIRLIE, KAUfFMAN Found., KaufFMan IndEX OF ENTREPRENEURIAL ACTIVTY 1996-2009 (2010), available at http://www.kauffman.org /uploadedfiles/kiea_2010_report.pdf (noting that the entrepreneurial activity ratethe percentage of American non-business owning adults who start a business each month-increased slightly in 2008 over 2007).

${ }^{92}$ See W. Mark Crain, Small Bus. Admin., Office of Advocacy, The Impact of REGULATORY COSTS ON SMALL FIRMS 5-6 (2005), available at http://www.sba.gov/sites/default/files/The_Impact_of\%20_Regulatory_Costs_of_ Small\%20Firms.pdf. 
further drain their resources, potentially deterring investment and entry. ${ }^{93}$ Moreover, if the PTO grants broad business and service process patents, small start-up businesses would face an entirely new regime of business regulation-essentially requiring businesses to request private permits to operate from their competitors who have patents, independent of whatever technology the new business uses to compete. A prohibition on such broad patenting is strongly supported by the "clues" that processes with wide-ranging applications, that constitute basic concepts, or that contain fundamental economic principles are more likely to be abstract ideas and should not be patentable. ${ }^{94}$

The potential for follow-on innovation is another reason to heavily scrutinize business and service process patent applications. In an ideal marketplace, one firm often discovers an innovative aspect of the business and others quickly follow, experimenting and modifying the original method or product to find other advances. ${ }^{95}$ In technological industries, follow-on innovation is often impeded by a plethora of preexisting patents. In patent-intensive industries, firms often develop large patent portfolios in order to navigate these so-called "patent thickets." While this often leads to market inefficiencies, many technology industries have adapted reasonably well to the existence of patent thickets in their fields because they must already invest in patents in order to offset the significant R\&D costs they are incurring. ${ }^{97}$

In many business and service industries, however, this is not the case. These firms have traditionally not sought or obtained patent protection. If some firms can easily acquire broad and potentially abstract patents on these methods, competing firms and new market entrants may have little choice but to develop defensive patent portfolios and blocking patents of their own in order to avoid the potential catastrophic risk of injunctions on their primary business models. ${ }^{98}$ Ironically, in order to acquire these

${ }^{93}$ See Bilski v. Kappos, 130 S. Ct. 3218, 3255-56 (2010) (Stevens, J., concurring) (noting substantial costs that will likely be imposed on businesses by increased business method patenting).

${ }^{94}$ See supra notes 23-25 and accompanying text. See also Bilski, $130 \mathrm{~S}$. Ct. at 3229 (majority opinion) ("The Information Age empowers people with new capacities to perform statistical analyses and mathematical calculations with a speed and sophistication that enable the design of protocols for more efficient performance of a vast number of business tasks. If a high enough bar is not set when considering patent applications of this sort, patent examiners and courts could be flooded with claims that would put a chill on creative endeavor and dynamic change.").

${ }^{95}$ See Alan Greenspan, Chairman, Fed. Reserve Bank, Remarks at the 2003 Financial Markets Conference of the Federal Reserve Bank of Atlanta: Market Economies and Rule of Law (Apr. 4, 2003), available at http:/ / www.federalreserve.gov /BoardDocs/speeches/2003/20030404/default.htm.

${ }^{96}$ Carl Shapiro, Navigating the Patent Thicket: Cross Licenses, Patent Pools, and Standard-Setting, 1 INNOVATION POL'Y \& ECON. 119, 120-21 (2001).

${ }^{97}$ See id. at $120,129-30$.

${ }^{98}$ See, e.g., NTP, Inc. v. Research in Motion, Ltd., No. 3:01CV767, 2003 U.S. Dist. LEXIS 26837, at *5 (E.D. Va. Aug. 5, 2003) (staying permanent injunction of RIM's 
patents, business and service firms would have to divert resources away from their R\&D budgets in order to pay legal fees and PTO fees, thereby potentially reducing innovation in their fields. ${ }^{99}$ All of this goes against the current settled expectations of innovators and investors in these fields. ${ }^{100}$

The potential perils of patent protection in the context of financial innovation are particularly ominous. A chief driver behind financial innovation is to make profits through perfect or near-perfect arbitrage. In other words, by repackaging and restructuring existing financial assets in new forms or combinations, arbitragers can take advantage of price discrepancies between two otherwise equivalent bundles of assets. Arbitrage is a fundamental activity in financial markets. Moreover, it is one that has been quite active since at least the middle ages, when Venetian bankers were able to exploit regional differences in gold/silver exchange rates to turn a considerable profit. ${ }^{101}$ Because arbitrage activities offer short-term profits that are often close to risk-free, such activities do not need the decades-long protection of patents to incentivize their innovation and use.

Moreover, the activities of quick-acting arbitrageurs are critical to efficiency and price discovery in financial markets. Virtually every accepted technique within financial engineering for valuing financial assets, from the Capital Asset Pricing Model to Arbitrage Pricing Theory to the Black Scholes options pricing formula, depends critically on the existence of arbitrageurs who will identify and quickly dissipate arbitrage opportunities. ${ }^{102}$

By its very nature, patent protection allows a patentee to delay her activities of profit extraction, unafraid of competition by others. In an arbitrage context, this implies that a patentee arbitrageur may decide to "milk" her strategy for many months, years, or even decades, and her property right to exclude others from the same strategy will induce her

Blackberry Wireless Email Service pending appeal due in part to a "demonstrated and increasing use" by the public); BESSEN \& MEURER, supra note 68, at 176 (noting evidence of large incumbents using patent injunctions anti-competitively as a means of discouraging entry by small inventors). See also generally Colleen V. Chien, Of Trolls, Davids, Goliaths, and Kings: Narratives and Evidence in the Litigation of High-Tech Patents, 87 N.C. L. REv. 1571, 1582-83 (2009) (describing the need for defensive patenting in patent-intensive industries).

${ }^{99}$ See Graham et al., supra note 69, at 1311 (noting that many startups, even in technology sectors, do not file patents because of their high cost).

${ }_{100}$ See Bilski v. Kappos, 130 S. Ct. 3218, 3255 (2010) (Stevens, J., concurring) (noting that "[i]nnovation in business methods is often a sequential and complementary process in which imitation may be a 'spur to innovation' and patents may 'become an impediment.") (quoting James Bessen \& Eric Maskin, Sequential Innovation, Patents, and Imitation, 40 RAND J. ECON. 61 1, 613 (2009)).

${ }^{101}$ See IVo WELCH, CORPORATE FINANCE: AN INTRODUCTION 248 (2009).

102 See, e.g., Mark Grinblatt \& Sheridan Titman, Financial Markets and CORPORATE STRATEGY 230-31 (2d ed. 2002) (discussing the critical role of arbitrage in financial derivatives pricing). 
arbitrage position to become relatively gradual. Thus, application of the constitutional and statutory clues to scrutinize financial patents would help ensure market efficiency, price discovery, and the viability of benchmark valuation models in finance. This also comports with the Bilski Court's finding that attempts to patent fundamental economic practices should generally be rejected as attempts to patent abstract ideas. $^{103}$

\section{USING ABSTRACTNESS CLUES TO CLOSELY SCRUTINIZE PATENT APPLICATIONS ON BUSINESS AND SERVICE PROCESSES WILL IMPROVE ADMINISTRATIVE AND JUDICIAL EFFICIENCY}

Applying the clues to patentability discussed above will also help the PTO and the courts to use public resources more appropriately. Whether a claim qualifies as patentable subject matter under $\S 101$ is a threshold inquiry. ${ }^{104}$ Any claim that fails to meet the requirements of $\S 101$ must be rejected, even if the requirements of $\S \S 102,103$, and 112 are met. ${ }^{105}$ Therefore, a robust set of $\$ 101$ clues for abstractness can help improve patent quality and the efficiency of decision-makers who examine and decide patent subject matter eligibility.

\section{A. Use of Robust $\$ 101$ Clues Allows the PTO to Efficiently Reject Abstract Patent Applications}

A robust set of $\S 101$ clues to abstractness gives the PTO a meaningful, efficient, and predictable framework against which to test patent applications at the threshold of the examination process, before significant costs are incurred. Every year, the PTO struggles to review and grant patents on appropriate inventions. The longer the PTO takes to review applications, the less protection and the fewer incentives are returned to innovators. ${ }^{106}$ Since State Street, there has been a dramatic increase in the number of business and service method patent applications, adding to this problem. ${ }^{107}$ After Bilski, the PTO and the courts will need to rely even more heavily on the clues to patentability in order to prevent threats to freedom to innovate from abstract patent claims.

${ }^{103}$ Bilski, 130 S. Ct. at 3231.

${ }^{104}$ See id. at 3225 ("The $\$ 101$ patent-eligibility inquiry is only a threshold test.").

${ }^{105}$ See 35 U.S.C. $\$ 103$ (2006); 35 U.S.C. $\$ 112$ (2006); Diamond v. Diehr, 450 U.S. 175, 188-91 (1981); Kewanee Oil Co. v. Bicron Corp., 416 U.S. 470, 483 (1974); 35 U.S.C. $\S 102$ (2006).

${ }^{106}$ See JAFFE \& LERNER, supra note 72 , at 131, 185-86.

107 Kevin M. Baird, Business Method Patents: Chaos at the USPTO or Business as Usual?, 2001 U. ILL. J.L. TECH. \& POL'Y 347, 348 (2001) (noting backlog of business method applications at the USPTO). 
Issuing a $\$ 101$ rejection is among the easiest ways for the PTO to take final action on patent applications. ${ }^{108}$ Unlike rejections under $\S 102$ (lack of novelty) or $\S 103$ (obviousness), $\S 101$ determinations are made on the claim language alone and thus do not require extensive research into the state of the art or the details of other documents. This can save examiners significant research time and lead to faster rejections of abstract applications.

For example, consider the following method from an actual application for directing funds to a charity, in which the primary claim is:

A method of directing funds to a charity, comprising:

receiving a first signal from a donor computer, the first signal including instructions, a request or advice indicating a desire to direct one or more payments to a donor-selected charity, at least a portion of the payment to be transferred from a giving account, the giving account having been established to hold funds for charitable gift-giving.

This is essentially an abstract process for charity fund-raising. It embodies a "basic concept" much like the patent claim in Bilski and does not advance the development, understanding, or application of a machine, a manufacture, or a composition of matter. Instead, much like Judge Rich's example of a diaper service, it merely uses technology (a donor computer) as an insignificant part of its solution without promoting its progress. Using the abstractness clues, the PTO could easily and quickly reject this application and focus its resources on other applications of more merit.

\section{B. Use of Robust $\$ 101$ Clues Allows Courts to Efficiently Dismiss Frivolous Patent Litigation}

Beyond the PTO, a set of robust $\S 101$ clues would also empower courts to reject patent claims that were erroneously granted to improper subject matter. Much has been made of the avalanche of patent litigation in the federal court system, especially as it relates to so-called "patent trolls"-entities that acquire patents for rent-seeking but which do not actually produce products covered by the patent. ${ }^{110}$ As Justice Kennedy recently observed: "An industry has developed in which firms use patents not as a basis for producing and selling goods but, instead, primarily for

${ }^{108}$ See In re Bilski, 545 F.3d 943, 950 n.1 (Fed. Cir. 2008) (en banc) (noting that a PTO examiner may reject a claim solely on the basis of $\S 101$ and independently of any other substantive requirement and suggesting that examiners first identify and reject claims on that basis). See also Interim Guidance, supra note 11, at 43923 (instructing examiners to reject claims under $\S 101$ if there is a prima facie case of subject matter ineligibility and then consider rebuttal arguments and evidence if presented).

${ }^{109}$ U.S. Patent Application No. $2006 / 0212390$ (filed Mar. 15, 2006).

110 See, e.g., Chien, supra note 98 , at $1577-82$. 
obtaining licensing fees."11 These lawsuits are problematic because they are so costly. ${ }^{112}$ Rarely does one win or lose such cases on summary judgment. Parties often have little choice but to settle to avoid the cost of litigating through trial and possible appeal. ${ }^{113}$

Utilizing the clues of $\S 101$ will allow at least some defendants who are fighting patent trolls and other suspect litigants to bring relatively straight-forward motions to dismiss and for summary judgment on $\S 101$ issues. ${ }^{114}$ This could have a substantial effect on reducing unwarranted and inappropriate patent litigation in the federal court system. ${ }^{115}$

\section{CONCLUSION}

In his Bilski concurrence, Justice Stevens expressed a "real concern that patents on business methods would press on the limits of the 'standard expressed in the Constitution,' more likely stifling progress than 'promot[ing]' it." business methods can qualify as patentable processes, we believe this concern remains. To address it, the PTO and the courts should fully embrace the constitutional, statutory, and judicial clues outlined above in light of the policy objectives we have described to help determine whether such methods are abstract ideas or concrete processes.

${ }^{\prime \prime \prime}$ eBay Inc. v. MercExchange, L.L.C., 547 U.S. 388, 396 (2006) (Kennedy, J., concurring).

${ }^{112}$ See, e.g., JAFFE \& LERNER, supra note 72 , at 76.

113 See id. at 14.

${ }^{114}$ See AT\&T Corp. v. Excel Commc'ns, Inc., 172 F.3d 1352, 1355 (Fed. Cir. 1999) (noting, on appeal from a motion for summary judgment, that $\S 101$ determinations are an issue of law).

115 Compare John R. Allison \& Mark A. Lemley, Empirical Evidence on the Validity of Litigated Patents, 26 AIPLA Q.J. 185, 187, 208 tbl. 1 (1998) (finding that from 1989 through 1996, even before State Street, expansive subject matter doctrines resulted in less than $1 \%$ of patents being invalidated by courts for improper subject matter), with CyberSource Corp. v. Retail Decisions, Inc., 620 F. Supp. 2d. 1068, 1081 (N.D. Cal. 2009) (ruling, after the Bilski en banc decision, that a business method patent was invalid subject matter on motion for summary judgment and observing that " $[\mathrm{t}] \mathrm{he}$ closing bell may be ringing for business method patents"), Fort Props., Inc. v. Am. Master Lease, LLC, 609 F. Supp. 2d 1052 (C.D. Cal. 2009) (holding a real estate business method patent invalid under Bilski's machine-or-transformation test), and Research Corp. Techs. v. Microsoft Corp., No. CV-01-658-TUC-RCJ, 2009 WL 2413623, at *9 (D. Ariz. July 28, 2009) (holding two patents invalid on motion for summary judgment under Bilski's machine-or-transformation test).

${ }^{116}$ Bilski v. Kappos, 130 S. Ct. 3218, 3253 (2010) (Stevens, J., concurring) (alteration in original) (quoting Graham v. John Deere Co. of Kan. City, 383 U.S. 1, 6 (1966) and U.S. CONST. art. I, \& 8, cl. 8). 
